\title{
Impelementasi Pemeliharaan Jiwa (Hifz Al-Nafs) Pada Pengasuhan Anak Berbasis Keluarga
}

\author{
Aay Siti Raohatul Hayat \\ Pascasarjana UIN Walisongo Semarang, Indonesia \\ aaysitiraohatulhayat917@gmail.com
}

\begin{abstract}
The formula for nurturing the soul always receives interesting discussions, likewise the SOS Children's Village as the largest non-governmental organization dedicated to caring for children who are abandoned and have lost their parents. The SOS Children's Village of Semarang believes that every child deserves to have a loving home by giving children supports they need to grow strong in sustaining life. This article focused on the discussion on how SOS Children's Village formulates hifz al-nafs by means of parenting styles applied in SOS. The phenomenological approach was used to see how the formulation of soul care was applied by SOS, so that the maintenance of the soul as a part of maqāsid al-sharī'ah could be more unique due to the emphasis on applicative and empirical nourishment of the soul. SOS had three (3) work programs, namely family-based care, family strengthening programs, and disaster emergency response. The three programs were oriented towards fulfilling children's rights as an effort to nurture children's souls so that they could grow and develop like children with nuclear families, where children who lost their care would live in an SOS village with a substitute family. This concept of care involved a foster mother in each house as the center of care, other children as siblings in the family home, and the SOS Family Village. The forms of care provided by the foster mother included paying attention, supervising, interacting and giving support to the SOS children. Also, the values conveyed in this parenting included religion, love and affection, responsibility and discipline.
\end{abstract}

Keywords: Nourishes The Soul (Hifẓ Al-Nafs), SOS Children's Village

\section{Abstrak}

Formula pemeliharaan jiwa tidak pernah bosan untuk selalu dibahas, begitupun dengan SOS Children's Village yang merupakan lembaga non pemerintah terbesar yang mendedikasikan diri untuk pengasuhan anak-anak yang ditinggalkan dan kehilangan orang tua. SOS Children's Villages Semarang percaya bahwa setiap anak berhak mendapatkan rumah yang penuh kasih sayang dengan memberi dukungan yang anak-anak butuhkan untuk

FOKUS : Jurnal Kajian Keislaman dan Kemasyarakatan Vol. 5, No. 2, 2020

LPPM Institut Agama Islam Negeri (IAIN) Curup - Bengkulu

p-ISSN 2548-334X, e-ISSN 2548-3358

DOI: $10.29240 /$ jf.v5i2.1404 | p 151-170 
tumbuh kuat dalam melangsungkan kehidupan. Artikel ini memfokuskan pembahasan tentang bagaimana SOS Children's Village memformulasikan hifz al-nafs dengan pola pengasuhan yang diterapkan di SOS. Pendekatan fenomenologi dipakai untuk melihat bagaimana formulasi pemeliharaan jiwa diterapkan oleh SOS, sehingga pemeliharaan jiwa yang merupakan bagian dari maqāșid al-sharī'ah menjadi lebih unik karena menekankan pada pemeliharaan jiwa secara aplikatif dan empiris. SOS mempunyai tiga (3) program kerja yaitu pengasuhan berbasis keluarga, rogram penguatan keluarga, dan tanggap darurat bencana. Ketiga program tersebut tidak lain untuk memenuhi hak-hak anak sebagai upaya pemeliharaan jiwa pada anak agar tumbuh kembang selayaknya anak-anak yang memiliki keluarga inti, dimana anak-anak yang kehilangan pengasuhan akan tinggal di sebuah desa SOS bersama keluarga pengganti. Konsep pengasuhan ini melibatkan seorang ibu asuh disetiap rumah sebagai sentral dalam pengasuhan, anak-anak lain sebagai kakak-beradik dalam rumah keluarga, dan desa keluarga SOS. Bentuk pengasuhan yang diberikan ibu asuh diantaranya memperhatikan, mengawasi, berinteraksi dan memberi dukungan ke anak-anak SOS. Serta nilai-nilai yang disampaikan dalam Pengasuhan ini meliputi agama, cinta dan kasih sayang, tanggung jawab dan kedisiplinan.

Kata Kunci: Pemeliharaan jiwa (hifẓ al-nafs), SOS Children's Village, Pengasuhan Anak Berbasis Keluarga

\section{Pendahuluan}

Pemenuhan hak terhadap anak merupakan suatu kewajiban bagi setiap keluarga (orang tua) untuk memastikan keturunannya terpenuhi segala hakhaknya sebagai seorang anak, baik fisik, psikis, sosial maupun spiritual. ${ }^{1}$ Figur orang tua menjadi sentral bagi kembang-tumbuh anak pada masa dewasanya. Namun tidak semua anak memiliki kesempatan dan keberuntungan yang sama, baik disebabkan oleh orang tua yang gagal merawat rumah tangga menjadi harmonis sehingga mengakibatkan perceraian, atau disebabkan oleh kehilangan sosok orang tua sejak dini, sehingga ia tidak mendapatkan hak yang sudah seharusnya ia terima. Kendala demikian mengakibatkan tidak sedikit dari mereka yang dititipkan pengasuhannya kepada panti asuhan atau lembaga sosial sejenis.

Salah satu lembaga sosial yang memberikan kepedulian terhadap hal

1 M. Bagus Pujianto dan Mukayat Al-Amin, Konsep Pengasuhan Alternatif Perspektif Uu Perlindungan Anak Dan Hukum Islam Jurnal A-Hikmah: Jurnal Studi AgamaAgama/Vol. 2, No. 2, 2016 
tersebut adalah SOS Children's Village yang terletak di Kota Semarang. Lembaga tersebut merupakan yayasan yang bergerak di bidang sosial, diantaranya adalah menerima anak-anak yang kehilangan dan hampir kehilangan figur orang tua atas dasar rekomendasi dari Kementrian Dinas Sosial (KEMENDINSOS). Anak yang tidak memiliki keluarga atau anak yang dengan latar belakang tidak mampu dapat melangsungkan hidup dan mendapatkan haknya di Desa Taruna Semarang tersebut. SOS Children's Village menawarkan beberapa program, diantaranya: Family Based Care (FBC)/Pengasuhan Berbasis Keluarga yaitu memastikan anak-anak dapat memiliki rumah, Ibu, kakak, dan adik selayaknya sebuah keluarga meskipun anak tersebut kehilangan pengasuhan orang tua, sekaligus membentuk sebuah komunitas yaitu Desa Anak, diharapkan mereka bisa memiliki masa depan yang lebih layak dan baik; ada juga Family Strengthening Program/Program Penguatan Keluarga. Melalui program ini SOS Children's Villages berusaha dan bekerja sama dengan keluarga-keluarga di sekitar SOS Village memberikan berupa bantuan biaya pendidikan kepada anak-anak, menyediakan makanan bergizi, dan akses kesehatan; program terakhir yaitu Emergency Response Program (ERP)/Tanggap Darurat Bencana. Menurut SOS, ketika terjadi suatu bencana, anak-anak merupakan kelompok yang paling rentan terkena dampak, mulai dari kehilangan akses pendidikan, kehilangan keluarga, hingga meninggalkan trauma mendalam. Oleh karenanya SOS Children's Villages Indonesia bekerja untuk memastikan bahwa setiap anak yang terdampak bencana tetap mendapatkan hak-haknya serta terlepas dari trauma bencana melalui program bantuan langsung serta memfasilitasi semua kegiatan anak termasuk pendidikan, bermain, serta trauma healing pada anak. ${ }^{2}$

Sikap peduli kemanusiaan yang dilakukan oleh SOS Children's Village sesuai dengan spirit Islam yang menjungjung tinggi nilai-nilai kemanusian. Islam sebagai agama rahmatan lil 'alamin sangat memperhatikan konsep pemeliharaan jiwa (hifz al-Nafs) baik dalam tingkat dlarruriyat, Hajiyat dan Tahsiniyat. ${ }^{3}$ Konsep ini terimplementasi di SOS Children's Village dengan design pengasuhan berbasis keluarga, bagi anak-anak yang kehilangan dan hampir kehilangan pengasuhan orang tua/keluarga. Sosok keluarga yang

\footnotetext{
${ }^{2}$ https://www.sos.or.id/tentang-sos/program

3 Jasser Audah, Maqāṣid Al-Sharī'ah As Philosophy of Islamic Law: a System Approach (Washington: The International Institite of Islamic Thouht, 2007) 24
} 
seharusnya melakukan peran tersebut akan tetapi tidak ditunaikan dengan baik dan diambil alih oleh yayasan yang memenuhi hak-hak anak tersebut. Artikel ini merupakan penelitian yang memfokuskan pembahasan tentang formulasi pemeliharaan jiwa (Hifz Nafs) dan pola pengasuhan sebagai implementasi maqūșid al-sharī'ah berbasis keluarga menggunakan pendekatan fenomenologi dengan lokus SOS Children's Villages. Sehingga pemeliharaan jiwa yang merupakan bagian dari maqāṣid al-sharī'ah menjadi lebih unik karena menekankan pada pemeliharaan jiwa secara aplikatif.

\section{Kerangka Pemeliharaan Jiwa (Hifz Al-Nafs) dalam Bingkai Maqashid Al- Syari'ah}

Maqāṣid al-syarīah merupakan makna, maksud, atau tujuan-tujuan yang ingin dicapai dalam hukum atau sederhananya dapat didefinisikan sebagai tujuan puncak (Ghāyah) dari syariat yang ada dibalik berlakukanya suatu hukum. ${ }^{4}$ Tujuan bukanlah ilat yang bersifat żāhir, mundabit, muta 'adi, dan munāsib li al-hikam. Tetapi tujuan disebut juga sebagai hikmah yang ada dibalik suatu hukum. Ulama kontemporer sepakat membagi maqāsid alsyarīah menjadi 3 (tiga) bagian, yaitu: Pertama, tujuan umum (al-maqāsid al' $\mathrm{amm}$ ) yaitu tujuan-tujuan yang ada dalam hukum-hukum Islam secara umum seperti al- darūriah al-khams dan ulama kontemporer menambahkan nilai keadilan, universalitas, dan kemudahan sebagai al-maqāsid al-'amm. Kedua, tujuan khusus (al-maqāsid al-khâshah) yaitu tujuan-tujuan yang diperhatikan dalam salah satu bab tertentu dalam hukum Islam seperti kesejahteraan anak dalam keluarga, mencegah kejahatan dalam hukum pidana dan mencegah monopoli dalam hukum muamalah. Ketiga, tujuan parsial (al-maqāsid aljuz'iyyah) yaitu tujuan-tujuan di balik suatu nash atau hukum tertentu seperti tujuan mengungkap kebenaran dalam penentuan jumlah saksi, maksud menghilangkan kesulitan dalam pembolehan orang sakit tidak berpuasa, dan tujuan menjamin fakir miskin dalam larangan menimbun daging kurban. Point penting dari adanya al-maqaashid al-syari'ah adalah menghilangkan kesulitan dan memberikan kemudahan bagi manusia. ${ }^{5}$

Mengikuti pemetaan di atas, hifz al-nafs tergolong dalam al-maqaashid al-'amm karena hifz al-nafs merupakan salah satu dari al-dharuriyyah al-

\footnotetext{
${ }^{4}$ Muhammad Abu Zahrah, Ushul al-Fiqh, terj. Saefullah Ma'sum, et al;ushul fiqh (Jakarta: Pustaka Firdaus), cet. Ix, 2005, 424

${ }^{5}$ Abdul Wahhab Khalaf, 'Ilm ushul al-Fiqh (Kairo: Maktabah Dakwah Islamiyah 1942), 116
} 
khams (lima keniscayaan). Lima keniscayaan ini berupa hifz̨ al-din (penjagaan agama), hifz al-nafs (penjagaan jiwa), hifz al 'aql (penjagaan akal), hifz al-nasl (penjagaan keturunan), dan hifz al-māl (penjagaan harta). Kelima hal tersebut disebut niscaya karena harus dipenuhi demi tegaknya kehidupan manusia untuk mewujudkan kemaslahatannya. Ketika salah satu darinya tidak ada, keberlangsungan hidup manusia akan terganggu dan terjadi kekacauan. ${ }^{6}$ Lima keniscayaan ini bukanlah berdasarkan petunjuk dari satu atau dua dalil saja namun merupakan hasil dari induksi terhadap nash, bahkan umat agamaagama lain pun menyepakati ini. ${ }^{7}$

Secara etimologi Hifz al-Nafs artinya menjaga jiwa, dan berasal dari gabungan dua kata bahasa arab yaitu حفظ yang artinya menjaga dan النفس yang artinya jiwa atau ruh. ${ }^{8}$ Sementara secara terminologi, Hifz al-Nafs adalah mencegah terjadinya hal-hal buruk dan memastikannya agar tetap hidup. ${ }^{9} \mathrm{Al}$ nafs dalam khasanah Islam memiliki banyak definisi, diantaranya dapat berarti jiwa, nyawa dan lain-lain. Semua potensi yang terdapat pada nafs bersifat potensial dan bisa teraplikasikan jika manusia selalu mengupayakan potensi tersebut. Setiap potensi yang ada pada nafs memiliki kecenderungan untuk membentuk kepribadian manusia meskipun hal tersebut dipengaruhi oleh faktor internal maupun eksternal. ${ }^{10}$ Hal tersebut termasuk dalam upaya pemeliharaan jiwa.

Al-Qur'an juga mendukung agar umat manusia melakukan pemeliharaan jiwa, termaktub dalam Q.S Al-Isra ayat 31:

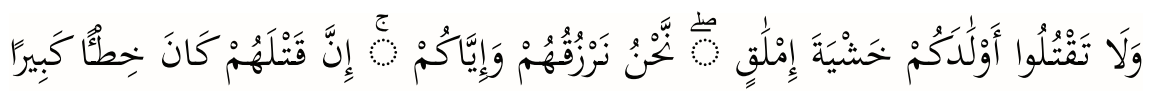

"Dan janganlah kamu membunuh anak-anakmu karena takut kemiskinan. Kamilah yang akan memberi rezeki kepada mereka dan juga kepadamu. Sesungguhnya membunuh mereka adalah suatu dosa yang besar. "11

Ayat di atas turun sebagai respon terhadap perilaku orang jahiliyyah

${ }^{6}$ Abd al-Wahhāb Khalaf, Ilm Ușūl al-Fiqh. Surabaya: al-Haramain, t.t.

${ }^{7}$ Abū Isḥāaq Ibrāhīm al- Syātibi, al-Muwāfaqāt. vol. 2, 31, 2000.

8 Ahmad Warson Munawwir, Kamus Al-Munawwir bahasa Arab-Indonesia, Yogyakarta: Pustaka Progresif, 1996, 279 dan 1446.

${ }^{9}$ Nuruddun Al-Mukhtar Al-Khadimi, Al-Munasabah Al-Syar'iyyah Wa Tatbiquha al-Mu'asiroh, Beirut: Dar Ibn Hazm, 2006, 77.

10 Abdul Mujib, Yusuf Mudzakir, Nuansa-nuansa Psikologi Islam, (PT. Raja Grafindo Persada, Jakarta, 2003), 46.

${ }^{11}$ Kementrian Agama RI, Al-Qur'an Terjemah dan Tajwid, Bandung: Sygma, 2014 
yang tidak memberikan hak waris kepada anak perempuan karena ia takut jatuh miskin. Menurut Ibn Katsir, ayat di atas menjelaskan tentang bukti kasih sayang Allah kepada anak yang memiliki hak untuk hidup, sehingga Allah melarang perilaku pembunuhan khususnya kepada anak. ${ }^{12}$

Q.S Al-Baqarah ayat 195

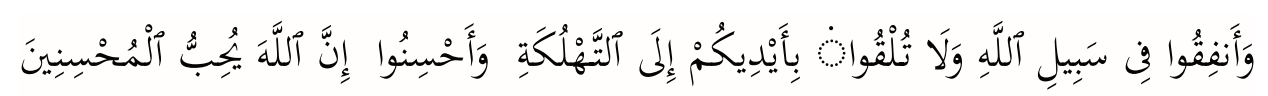

Dan infakkanlah (harta bendamu) di jalan Allah, dan janganlah kamu menjatuhkan dirimu sendiri ke dalam kebinasaan, dan berbuat baiklah, karena sesungguhnya Allah menyukai orang-orang yang berbuat baik. ${ }^{13}$

Ayat tersebut merupakan anjuran untuk menjaga diri agar tidak menjerumuskan diri kepada kebinasaan. Tindakan membinasakan diri pada ayat ini dapat diamaknai dengan du acara; pertama, kebinasaan yang dimaksud sesuai dengan konteks turun ayat, yaitu kebinasaan dengan tidak bejihad dan menginfakan harta di jalan Allah. Kedua, Kebinasaan yang dapat menghancurkan potensi positif yang ada dalam jiwa, baik fisik maupun psikis. ${ }^{14}$

Q.S Al-Baqarah ayat 72

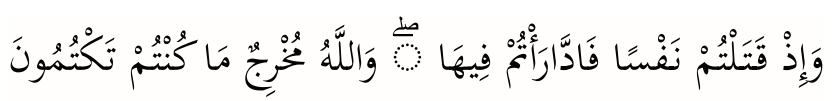

"Dan (ingatlah), ketika kamu membunuh seorang manusia lalu kamu saling tuduh menuduh tentang itu. Dan Allah hendak menyingkapkan apa yang selama ini kamu sembunyikan". ${ }^{15}$

\footnotetext{
${ }^{12}$ Ismail Ibnu Umar Ibnu Katsir, Tafsîr al-Qur'ân al- 'Azhîm, (Beirut: Dar al-Kutub al-Islamiyah, 1419), jilid v, 242

${ }^{13}$ Kementrian Agama RI, Al-Qur'an Terjemah dan Tajwid, Bandung: Sygma, 2014

${ }^{14}$ Syaikh Muhammad bin Shalih asy-Syawi, Al-Nafahât al Makiyyah fi Tafsîr Kitab Rabb al-Bariyyah, Abekan, t.t.

${ }^{15}$ Kementrian Agama RI, Al-Qur'an Terjemah dan Tajwid, Bandung: Sygma, 2014
} 
Q.S Al-Baqarah ayat 178

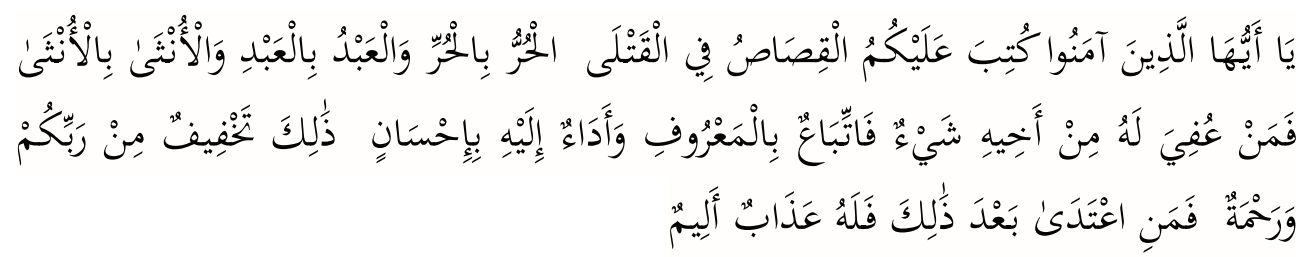

Hai orang-orang yang beriman, diwajibkan atas kamu qishaash berkenaan dengan orang-orang yang dibunuh; orang merdeka dengan orang merdeka, hamba dengan hamba, dan wanita dengan wanita. Maka barang siapa yang mendapat suatu pemaafan dari saudaranya, hendaklah (yang memaafkan) mengikuti dengan cara yang baik, dan hendaklah (yang diberimaaf) membayar (diyat) kepada yang memberi maaf dengan cara yang baik (pula). Yang demikian itu adalah suatu keringanan dari Tuhan kamu dan suatu rahmat. Barang siapa yang melampaui batas sesudah itu, maka baginya siksa yang sangat pedih. ${ }^{16}$

Pada prinsipnya, ayat di atas menjelaskan bahwa hukum qishash dilakukan atas dasar kesetaraan agar sama-sama menjaga hak hidup manusia. Adapun bila kejadinya tersebut telah dimaafkan maka hukum qishah gugur dan tidak boleh dilakukan.

Umat Islam berkewajiban untuk menjaga diri sendiri dan orang lain. Islam juga sangat mendukung agar saling menyayangi dan berbagi kasih sayang dalam bingkai ajaran agama Islam serta yang dicontohkan oleh Nabi Muhammad SAW. Jaminan keselamatan jiwa (al-Muhafadzah ala al-Nafs) ialah jaminan keselamatan atas hak hidup yang terhormat dan mulia. Termasukan dalam cakupan pengertian umum dari jaminan ini, ialah: jaminan keselamatan nyawa, anggota badan dan terjaminnya kehormatan kemanusiaan. Mengenai yang terahir ini, meliputi keterbatasan memilih profesi, kebebasan berfikir atau mengeluarkan pendapat, kebebasan berbicara, kebebasan memilih tempat tinggal dan lain sebagainya. ${ }^{17}$

\footnotetext{
${ }^{16}$ Kementrian Agama RI, Al-Qur'an Terjemah dan Tajwid, Bandung: Sygma, 2014

${ }^{17}$ Muhammad Abu Zahrah, Ushul Fiqh, (Jakarta: PT. Pustaka Firdaus, 2010), 425
} 
Memelihara jiwa berdasarkan tingkatannya dapat dibedakan menjadi tiga (3) yaitu:

1. Memelihara jiwa dalam tingkat daruriyat seperti memenuhi kebutuhan pokok dan bersifat primer yang apabila kebutuhan ini tidak terpenuhi, maka akan mengakibatkan terancamnya jiwa manusia.

2. Memelihara jiwa dalam tingkat hajiyat atau kebutuhan yang bersifat sekunder seperti dibolehkannya memiih dan menikmati makanan dan minuman yang lezat yang apabia kegiatan ini diabaikan maka tidak akan mengancam eksistensi manusia melainkan hanya akan mempersulit hidupnya saja.

3. Memelihara jiwa dalam tingkat tahnisiyat atau kebutuhan yang bersifat tersier seperti ditetapkannya tata cara makan dan minum. Hal ini, hanya berhubungan dengan masalah kesopanan, keindahan, dan sama sekali tidak akan mengancam jiwa manusia maupun mempersulit kehidupan manusia. ${ }^{18}$

Upaya memelihara jiwa Allah melarang segala perbuatan yang dapat merusak jiwa, seperti pembunuhan terhadap diri sendiri maupun orang lain, dan diisyaratkan hukum qisas bagi pelaku pembunuhan, tindakan makar, dan lain sebagainya. ${ }^{19}$

Memelihara keturunan bertujuan untuk menjamin keberlangsungan hidup manusia dari generasi ke generasi merupakan bentuk dari kemaslahatan baik duniawi atau ukhrawi. Karena itu syari' at memandang pentingnya naluri manusia untuk berketurunan dan syari'at mengatur pemeliharaan keturunan. Al-Qur'an juga mengatur hukum keluarga yang mencakup perintah membangun keluarga diatas landasan pernikahan yang sah, batasan jumlah istri, tata cara menggauli, talak, menafkahi istri, tanggung jawab terhadap anak-anak yang lahir, serta larangan menghardik anak yatim, serta menindas kaum yang lemah.

\section{Profil SOS Children's Village Semarang}

SOS Children's Villages merupakan organisasi sosial non-profit yang mendukung pemenuhan kebutuhan hak-hak anak dan berkomitmen memberikan pengasuhan berbasis keluarga. Anak-anak yang tinggal merupakan mereka yang telah kehilangan pengasuhan atau berpotensi kehilangan pengasuhan orang tua. Kehilangan pengasuhan orang tua berarti

\footnotetext{
${ }^{18}$ Sapiudin Shidiq, Ushul Fiqh, (Jakarta: Kharisma Putra Utama, 2011), 228

${ }^{19}$ Alaiddin Koto, Ilmu Fiqh dan Ushul Fiqh, (Jakarta: PT. Raja Grafindo Persada, 2004), 123
} 
anak-anak tidak mendapatkan perlakuan dan perhatian tentang pendidikan, kesehatan dan pengasuhan (kasih sayang, hak hidup, perhatian dari keluarga). Lembaga yang berdiri sejak tahun 1949 telah ada di 133 negara termasuk Indonesia. Di Indonesia tersebar di 8 kota yaitu Lembang, Cibubur, Semarang, Tabanan, Flores, Banda Aceh, Meulaboh, dan Medan. ${ }^{20}$

Kata "SOS" saat awal berdiri dahulu merupakan singkatan dari Societe Societas yang merupakan bahasa latin, artinya Paguyuban Pengasuhan. Tetapi ada juga yang mengatakan "SOS" adalah Save Our Soul, yang memiliki arti Selamatkan Jiwa Kami. Sedangkan sekarang kata "SOS" telah menjadi brand, jadi bukan merupakan suatu singkatan. Brand adalah sesuatu yang menunjukkan khas yang sudah paten. ${ }^{21}$

SOS Children's Village Semarang diresmikan pada tanggal 31 Januari 1985 diresmikan langsung oleh Hermann Gmeiner selaku pendiri SOS Children's Villages Internasional. SOS Children's Village Semarang diketuai oleh Lucas Formiatno selaku Village diraector. SOS Children's Village Semarang terletak di Kecamatan Banyumanik, Semarang, provinsi Jawa Tengah yang berada di pesisir utara pulau Jawa. Target group penerimaan anak asuh yaitu terdiri atas anak yang terlantar, anak yatim, dan anak piatu. Penerimaan anak asuh melalui proses prosedural yang cukup panjang, melaui DPA (dewan penerimaan anak) dan rekomendasi dari Dinas Sosial. ${ }^{22}$

Adapun tujuan SOS Children's Village Semarang diantaranya meliputi:

1. Pengasuhan; a) Pengasuhan langsung, b) Perlindungan, c) Pangan dan nutrisi, d) Papan

2. Pendidikan; a) Pendidikan formal, b) Pendidikan non formal, c) Pendidikan informal

3. Kesehatan; a) Kesehatan preventif, b) Kesehatan kuratif, c) Bantuan psiko$\operatorname{sosial}^{23}$

SOS Desa Taruna Terdiri dari 14 rumah keluarga (5 rumah keluarga Muslim, 7 rumah keluarga Katholik, dan 2 rumah keluarga Kristen Protestan), sebuah rumah pimpinan desa, rumah untuk tante (asisten ibu yang membantu

\footnotetext{
${ }^{20}$ https://www.sos.or.id/semarang

${ }^{21}$ https://www.sos.or.id/semarang dan diperkuat dengan pernyataan Pak Ardik ketika Wawancara pada 09 Januari 2020.

${ }^{22}$ Wawancara Village CP Vocal Person SOS Children's Villages Semarang, Ardik Setiawan, 09 Januari 2020.

${ }^{23}$ Hasil Observasi ke SOS Children's Village Semarang pada tanggal 9 Januari 2020.
} 
dan mendukung Ibu SOS) dan berbagai gedung administrasi yang berdiri diatas lahan lebih dari tiga hektar.Di lokasi ini setiap anak diasuh dengan ajaran agama masing-masing, baik yang beragama Islam, Katolik, dan Kristen Protestan. $^{24}$

Dalam Manual for the SOS Children's Village Organisation menyatakan bahwa lembaga ini memiliki visi berupa setiap anak adalah bagian dari sebuah keluarga, tumbuh dengan cinta, tumbuh dengan rasa hormat dan tumbuh dengan rasa aman. Misi SOS Children's Villages adalah membangun keluarga bagi anak yang kehilangan pengasuhan, membantu mereka membangun masa depan, dan mendukung pemberdayaan masyarakat. ${ }^{25}$

Selain visi dan misi yang jelas dan pengasuhan yang berbasis keluarga, SOS Children's Villages Semarang memberikandukungan kepada keluarga yang kurang beruntung dengan mengasuh lebih dari 102 anak melalui Family Strengthening Program (FSP) untuk mencegah terjadinya kondisi terburuk yang dapat menyebabkan anak terpisah dari keluarga biologisnya. ${ }^{26}$

Pengasuhan anak berbasis keluarga jangka panjang di SOS Children's Village Semarang berdasarkan empat prinsip:

1. Ibu Asuh. Setiap satu keluarga memiliki Ibu Asuh. Ibu Asuh merupakan seseorang yang dipercaya untuk membimbing, merawat dan mengasuh anak-anak yang dititipkan padanya. Sebagai ibu pengasuh, tanggung jawab ibu asuh sangatlah besar dan menjadi inti dari kenyamanan setiap anak di dalam keluarga yang dibina dan dibimbingnya. Dalam menjalankan segala tugas dan urusan dalam rumah tangga itu menjadi tanggung jawab ibu pengasuh. Ibu Asuh menjadi subyek utama yang mengetahui perkembangan setiap anak asuh yang dibinanya. Sehingga keberadaan ibu asuh sangat diperhitungkan. Untuk menjadi ibu asuh di SOS harus melalui tahapan seleksi, dan mau berkomitmen untuk ikut serta mewujudkan visi misi SOS dalam melayani dan memberikan pengasuhan yang baik untuk anak-anaknya.

${ }^{24}$ Wawancara Village CP Vocal Person SOS Children's Villages Semarang, Ardik Setiawan, 09 Januari 2020.

${ }^{25}$ SOS Kinderdorf International, 2004.

${ }^{26}$ Wawancara Village CP Vocal Person SOS Children's Villages Semarang, Ardik Setiawan, 09 Januari 2020. 
2. Kakak dan adik. Ikatan Keluarga tumbuh secara alamiah, dimana setiap keluarga (satu rumah) memiliki anggota yang terdiri dari laki-laki dan perempuan. Mereka hidup saling melengkapi satu dengan yang lain dan membangun sebuah ikatan emosional yang berlangsung dengan baik. Meski berasal dari latar belakang usia dan keluarga yang berbeda, tetapi mereka menjadi saudara sebagaimana saudara sekandung dalam keluarga.

3. Rumah. Setiap keluarga menciptakan suasana rumah yang nyaman. Rumah menjadi lingkungan utama anak-anak membangun diri, melakukan segala jenis kegiatan yang mampu menciptakan suasana baru bagi dirinya setiap saat. Oleh karenanya rumah harus dibangun dan dibentuk senyaman mungkin agar setiap anggota keluarga betah untuk tinggal dan berlindung di sana. Anak-anak juga dibina untuk memiliki tanggung jawab dalam memelihara rumah melalui pembagian tugas masing-masing dengan tujuan untuk menciptakan rasa memiliki atas rumah tersebut.

Dalam satu rumah terdiri dari 1 (ibu asuh) dan 8 anak campur antara lakilai dan perempuan, dan pengelompokan anak asuh dilakukan berdasarkan persamaan agamanya dengan maksud agar mereka mendapatkan pendidikan agama di bawah pimpinan seorang ibu pengasuh dengan agama yang sama.

SOS Children's Village Semarang memiliki 102 anak asuh dengan rincian 70 anak tinggal di Village, selebihnya ada yang sudah tinggal di rumah remaja (khusus laki-laki), dan tempat kost. Dengan ketentuan apabila anakanak sudah masuk kelas 1 SMP Sederajat maka harus tinggal di rumah remaja; dan bagi yang sudah memasuki jenjang perkuliahan, anak boleh memilih untuk nge-kost akan tetapi masih dalam pantauan SOS Children's Village. ${ }^{27}$

4. Desa. Setiap keluarga merupakan bagian dari masyarakat Keluarga SOS Children's Village, mereka tinggal dalam sebuah desa yang aman dan nyaman yang mendukung setiap penghuninya menikmati suasana gembira dalam komunitas masyarakat kecil namun memiliki rasa kekeluargaan yang tinggi. Meski telah memiliki satu pengasuh dalam sebuah rumah, tetapi semua pengasuh mereka anggap ibu mereka sendiri. Setiap anggota keluarga dibina dan dididik menjadi orang yang bertanggung jawab dalam lingkungan dan kebudayaan yang sama. Hal ini sangat penting agar di hati

${ }^{27}$ Wawancara Village CP Vocal Person SOS Children's Villages Semarang, Ardik Setiawan, 09 Januari 2020. 
setiap anak terdapat rasa saling memiliki dan tetap mengingat satu sama lain terutama di masa yang akan datang setelah mereka mandiri. ${ }^{28}$

Berdasarkan Undang-undang nomor 6 Tahun 1974 tentang ketentuan pokok kesejahteraan sosial bahwa, setiap warga Negara berhak atas taraf sosial yang sebaik-baiknya, maka kesejahteraan anak merupakan hal yang perlu mendapat perhatian, karena masih banyak anak-anak yang tidak dapat menikmati masa kanak-kanaknya yang menyenangkan karena kondisi yang dihadapinya dan keadaan orang tuanya. ${ }^{29}$

\section{Pengasuhan Berbasis Keluarga SOS Children's Village sebagai Implementasi Hifz al-Nafs}

Pengasuhan berbasis keluarga adalah pengasuhan yang tidak tinggal dipanti, melainkan tinggal bersama keluarganya di rumah dan pengasuhan itu dilakukan oleh pihak-pihak diluar keluarga inti atau kerabat anak. ${ }^{30}$ Akan tetapi, di SOS semua anak tinggal di desa tersebut semua kegiatas dilakukan terpusat di Village tersebut. Semua kegiatan di Village sudah terjadwal dari sepulang sekolah sampai menjelang tidur malam. ${ }^{31}$

Semua anak yang berada dalam satu keluarga merupakan anak-anak dari latar belakang yang berbeda-beda. Mereka didoktrin bahwa dalam keluarga tersebut merupakan keluarga yang utuh, terdapat kakak dan adik, ibu, dan bapa sehingga tumbuh rasa saling memiliki, saling menyayangi, dan saling menghormati. Menurut pernyataan pihak SOS, pengasuhan berbasis keluarga yang diterapakan di SOS sudah diakui secara de jure dan de facto dan telah terakreditasi A pada tahun 2017. ${ }^{32}$

Semua kegiatan dilakukan oleh semua anak SOS, akan tetapi pada beberapa agenda yang menyangkut keagamaan dibedakan sesuai dengan agama dan kebutuhan anak tersebut. Anak-anak tersebut dibimbing dan dididik oleh ibu asuh yang keyakinanya sama dengan anak tersebut. Segala

\footnotetext{
${ }^{28}$ Wawancara Village CP Vocal Person SOS Children's Villages Semarang, Ardik Setiawan, 09 Januari 2020

${ }^{29}$ Sumarnonugroho, T, Sistem Intervensi kesejahteraan Sosial, Yogyakarta : PT Hanindit, 1987.

30 Peratutan Menteri Sosial RI No. 30/HUK/2011 tentang standar Nasional Pengasuhan Anak Lembaga Kesejahteraan Sosial Anak, Jakarta: Kementrian Sosial, 2011, 50.

${ }^{31}$ Wawancara Village CP Vocal Person SOS Children's Villages Semarang, Ardik Setiawan, 09 Januari 2020

${ }^{32}$ Wawancara Village CP Vocal Person SOS Children's Villages Semarang, Ardik Setiawan, 09 Januari 2020
} 
bentuk kebutuhan, baik dalam hal pemenuhan kebutuhan sekolah, kebutuhan makan, kebutuhan sosok/figur orang tua, semuanya diberikan oleh ibu asuh. ${ }^{33}$ SOS Children's Village Semarang memiliki standar kebijakan perlindungan anak dengan prinsip dan kaitannya:

1. Pemahaman (awareness) mendobrak kebisuan dan tabu

a) Mengembangkan dan memelihara budaya keterbukaan dan responsif di SOS

b) Setiap orang di SOS mengerti akan perlakuan salah dan kaitannya terhadap anak

c) Anak-anak dan orang dewasa berkesempatan mendiskusikan perlindungan anak secara berkala

d) Meningkatkan pemahaman perlindungan anak dengan memperkuat kemampuan oengasuhan yang positif di komunitas SOS.

2. Pencegahan (Prevention)-menciptakan dan mempertahankan lingkungan yang untuyk anak dan karyawan

a) Prosedur pemilihan dan

b) Pelatihan yang memadai untuk karyawan dan komitmen terhadap kode etik SOS

c) Memperkuat anak-anak untuk menjadi peserta aktif dalam perlindungan diri dan teman-temanya.

d) Lingkungan kerja yang memadai agar karyawan bisa menjaga keselamatan anak.

3. Pelaporan (reporting)- menanggapi semua hal dengan intensif

a) Tim perlindungan anak disemua lokasi program dan tingkat nasional

b) Tersedianya tempat pelaporan yang aman dan seimbang dan mudah dakses anak-anak

c) Pentingnya kerahasiaan untuk melindungi anak dari kekerasan berikutnya

d) Pelapor dipastikan aman dan terlindungi

4. Tanggapan (responding)- untuk kepentingan terbaik anak-anak yang terkait

${ }^{33}$ Santi Anjasari dan Sri Hartini, Upaya Pengelola Program Penguatan Keluarga SOS Children's Village Indonesia dalam Mengurangi Jumlah Anak-anak yang Rentan Terlantar, Jurnal COMM-EDU Vol 1 No. 1 Tahun 2018, 42. 2018. 
a) Harus sesalu ada respon sesuai sifat dan berat/ringannya pelanggaran

b) Kepemimpinan yang jelas dalam investigasi internal, pelaporan kepada dinas kesejahteraan dan dukungan tahapan penyembuhan bagi semua orang yang terkena dampak

c) Selama kasus yang dilaporkan terdokumentasi, tercatat, dan tersimpan aman. ${ }^{34}$

SOS juga mengintruksikan agar seluruh karyawan SOS dan semua orang yang terlibat atau partisipan dalam program SOS, berkewajiban untuk melindungi anak-anak dari segala bentuk perlakuan salah (kekerasan fisik, sexual, emosional, serta kekerasan terhadap privasi anak), penelantaran dan eksploitasi. Selain itu, kami sangat mengutuk segala bentuk kekerasan serta eksploitasi anak, baik yang terjadi didalam maupun diluar organisasi, dan selalu merespon setiap kasus, baik pelecehan yang tebukti, dugaan maupun percobaan dalam lingkup pengaruh sesuai dengan sifat jenisnya. ${ }^{35}$

SOS sangat kecewa bagi tiap-tiap keluarga yang dengan atau tidak sengaja menelantarkan anaknya, membiarkan anaknya menjadi korban atas ketidakharmonisan pasangan dalam keluarga tersebut. Memberikan asuhan yang baik merupakan suatu keniscayaan yang patut diterima oleh anak. SOS berupaya dengan segala kekurangan yang ada mewujudkan tempat bagi anakanak yang kehilangan dan akan kehilangan pengasuhan dari orang tua kandungnya. Menciptakan kenyamanan bagi anak, memeuhi segala hak-hak anak dan dibekali pendidikan agar menunjang skill anak tersebut, serta diberkan edukasi bahwa suatu saat nanti anak tersebut harus menjadi orang tua yang bertanggung jawab dan memberikan pengasuhan yang baik untuk anakanaknya kelak.

Standar perlindungan anak yang diterapkan di SOS telah sejalan dengan maksud dari Undang-Undang No. 23 tahun 2002 tentang perlindungan anak yaitu Perlindungan anak dapat dilakukan secara langsung maupun tidak langsung. Secara langsung maksudnya kegiatannya langsung ditujukan kepada anak yang menjadi sasaran pelanggaran langsung. Kegiatan seperti ini dapat dengan cara melindungi anak dari berbagai ancaman dari luar dan dalam seperti mendidik, membina, mendampingi anak dengan berbagai cara.

\footnotetext{
${ }^{34}$ Hasil observasi ke SOS Children's Village Semarang

${ }^{35}$ Wawancara Village CP Vocal Person SOS Children's Villages Semarang, Ardik Setiawan, 09 Januari 2020.
} 
Perlindungan anak secara tidak langsung yaitu kegiatan tidak langsung ditujukan kepada anak, tetapi orang lain yang melakukan atau terlibat dalam usaha perlindungan anak. ${ }^{36}$

\section{Pengasuhan Anak Menurut Hukum Islam dan Hukum Positif}

Secara etimologis al-hadanah diambil dari kata al-hidn, yang berarti rusuk, yakni mengumpulkan ke rusuk. Kemudian kata Hadanah dipakai sebagai istilah dengan arti pengasuhan anak. Dimaknai demikian karena seorang ibu yang mengasuh atau menggendong anaknya, sering kali meletakkan pada sebelah rusuk atau dalam pangkuan sisi sebelah rusuk sang ibu. $^{37}$

Menurut Zuhaili, al-hadanah adalah mendidik dan memelihara orang yang tidak bisa mandiri dalam menangani urusan-urusan pribadi dari hal-hal yang tidak disukainya. Orang yang tidak bias mandiri itu misalnya karena ia belum tamyiz, seperti anak kecil dan orang gila. Tindakan tersebut dilakukan dengan cara melindungi segala urusan, mengatur makanan, minuman, pakaian, tidur, mandi, membersihkan diri, mencuci baju pada umur tertentu dan lain sebagainya. ${ }^{38}$

Hukum hak asuh dalam islam adalah wajib. Pasalnya anak adalah tanggung jawab orang tua. Mulai dari nafkah, pendidikan, tempat tinggal, perawatan, pengasuhan semuanya harus dipenuhi. Tidak boleh membiarkan anak tanpa penjagaan, terutama anak yang masih kecil yang mana bila ditelantarkan maka bias membahayakan nasibnya. Tentunya setiap anak butuh seorang wali, baik dari orang tuanya atau pun sanak keluarga. Itu bergantung pada kondisi masing-masing.

Majelis Ulama Indonesia (MUI) juga telah menjelaskan bahwa hukum hak asuh anak adalah wajib. Pernyataan tersebut didasarkan pada dalil-dalil Al-Quran dan Al-Hadist yang menekankan bahwa jangan sampai nasib anak setelah perceraian malah terabaikan. Orang tua memiliki kewajiban menjaga anak-anaknya hingga si anak telah menikah. Karena orang tua adalah orang yang pertama bertanggung jawab atas terwujudnya kesejateraan anak baik

\footnotetext{
${ }^{36}$ Maidin Gultom, Perlindungan Hukum Terhadap Anak; Dalam Sistem Peradilan Pidana Anak di Indonesia, Bandung: Refika Aditama, 2006, 38.

${ }^{37}$ Wahbah al-Zuhaili, Al-Fiqh al-Islami wa Adillatuh, (Damsyiq : Dar al-Fikr, 1989), VII : 717. lihat juga Kamal Muchtar, Asas-asas Hukum Islam Tentang Perkawinan, 126.

${ }^{38}$ Wahbah Zuhaili, Al-Fiqh al-Islami Wa Adillatuh, 718
} 
secara rohani, jasmani maupun sosial sebagaimana diamanatkan dalam Undang-undang Dasar 1945. ${ }^{39}$

Pengasuhan merupakan sejumlah kemampuan interpersonal dan mempunyai tuntutan emosional yang besar. Pelayanan pengasuhan berbagai jenis pelayanan yang diberikan untuk memenuhi kebutuhan anak akan pengasuhan, baik di dalam keluarganya maupun keluarga pengganti. Keluarga pengganti yang menggantikan peran keluarga inti untuk memberikan pengasuhan pada anak terdiri dari keluarga kerabat, keluarga asuh, wali, dan keluarga angka. ${ }^{40}$

Untuk mengatur kualitas pelayanan panti asuhan/yayasan sosial anak, Kementerian Sosial bekerjasama dengan save the Children, telah menyusun Standar Nasional Pengasuhan untuk Lembaga Kesejahteraan Sosial Anak/Panti Asuhan yang telah ditetapkan menjadi Peraturan Menteri Sosial No. 30/HUK/2011 tentang Standar Nasional Pengasuhan Anak untuk Lembaga Kesejahteraan Sosial Anak. Standar ini merupakan instrumen penting dalam kebijakan pengaturan pengasuhan alternatif untuk anak dan ditujukan untuk memperbaiki kualitas pelayanan panti/lembaga asuhan.

Standar nasional pengasuhan anak ini mengandung komponenkomponen utama pengaturan aspek-aspek antara lain:

1. Prinsip-prinsip pengasuhan anak termasuk tentang sistem pengasuhan alternative;

2. Pemenuhan semua aspek-aspek hak-hak anak baik kebutuhan dasar, kebutuhan pengasuhan anak, perlindungan, maupun partisipasi anak;

3. Transformasi peran Lembaga Kesejahteraan Sosial Anak/lembaga untuk mendukung pengasuhan keluarga dan pengasuhan alternatif berbasis keluarga. ${ }^{41}$

Komplikasi Hukum Islam (HKI) juga mengatur mengenai hak asuh anak, yakni di pasal 105 dan 156, yang menyebutkan bahwa hak asuh anak yang masih kecil (mummayiz) secara otomatis jatuh pada tangan ibunya.

\footnotetext{
${ }^{39}$ Noer Indriati, Krisnhoe K. Wahyuningsih, dan Sanyoto, Perlindungan dan Pemenuhan Hak Anak (Studi Tentang Orang Tua sebagai Buruh Migran di Kabupaten Banyumas), Jurnal Mimbar Hukum Vol 29 No. 3 tahun 2017, 484, 2017.

40 Peratutan Menteri Sosial RI No. 30/HUK/2011 tentang standar Nasional Pengasuhan Anak, 15.

${ }^{41}$ Kemensos,http://www.pksa/kemensos.com/wpcontent/uploads/2011/01/Pedoman _PKSA_2011. diakses pada 1 Januari 2010 pada pukul 11.48 Wib
} 
Kecuali pada kondisi-kondisi tertentu dimana si ibu dalam keadaan tidak baik secara mental atau agama, entah mungkin meninggal, maka hak asuh bisa beralih ke keluarga lainnya. ${ }^{42}$ Pasal-Pasal tersebut menerangkan tentang akibat dari perceraian.

Pasal-pasal KHI tentang hadanah tersebut menegaskan bahwa kewajiban pengasuhan material dan non material merupakan 2 hal yang tidak dapat dipisahkan. Lebih dari itu KHI malah menangani tugas-tugas yang harus diemban kedua orang tua kendatipun mereka berpisah, anak yang belum mumayiz tetap di asuh oleh ibunya sedangkan pembiayaan menjadi tanggung jawab ayahnya. Menurut UU Perkawinan, bahwa kewajiban orang tua terhadap anaknya pada dasarnya terbagi kepada 2 bagian yaitu pemeliharaan dan pendidikan. Kewajiban ini berlaku terus sampai anak tersebut kawin atau dapat berdiri sendiri walaupun perkawinan antara kedua orang tua itu telah putus. Sebagai landasan Hukum tentang kewajiban orang tua untuk memelihara dan mendidik anak-anak tersebut di dalam UU No. 1 Tahun 1974 tentang Perkawinan pasal 45 ayat 1 dan 2 di jelaskan tentang hak dan kewajiban antara orang tua dan anak yang berbunyi : (1) kedua orang tua wajib memelihara dan mendidik anakmereka sebaik-baiknya dan (2) kewajiban orang tua yang dimaksud dalam ayat (1) pasal ini berlaku sampai anak itu kawin atau dapat berdiri sendiri, kewajiban mana berlaku terus meskipun perkawinan antara kedua orang tua putus. ${ }^{43}$

\section{Kesimpulan}

SOS Children's Village merupakan lembaga sosial yang memberikan pengasuhan berbasis keluarga dan memiliki formulasi pemeliharaan jiwa ( $h i f z$ al-nafs) 3 program; Pertama, Family Based Care (FBC)/Pengasuhan Berbasis Keluarga yaitu memastikan anak-anak yang telah kehilangan pengasuhan orang tua dapat memiliki rumah, Ibu, kakak, dan adik selayaknya sebuah keluarga dan membentuk sebuah komunitas yang disebut sebagai Desa Anak, sehingga mereka bisa memiliki masa depan yang lebih baik. Kedua, Family Strengthening Program (FSP)/Program Penguatan Keluarga, Melalui program penguatan keluarga, SOS Children's Villages bekerja dengan keluarga-keluarga di sekitar SOS Village untuk mencegah terjadinya kondisi yang bisa menyebabkan seorang anak terpisah dari orang tuanya,

\footnotetext{
${ }^{42}$ Kompilasi Hukum Islam, pdf.

${ }^{43}$ UU No. 1 tahun 1974 tentang perkawinan, pdf.
} 
terutama karena faktor ekonomi. Dalam program ini, SOS Children's Villages melakukan intervensi langsung pada anak berupa bantuan biaya pendidikan, penyediaan makanan bergizi, dan akses terhadap kesehatan. Ketiga, Emergency Response Program (ERP)/Tanggap Darurat Bencana, SOS Children's Villages Indonesia bekerja untuk memastikan setiap anak yang terdampak bencana tetap mendapatkan hak-haknya serta terlepas dari trauma bencana melalui program bantuan langsung dan pendirian children center yang memfasilitasi semua kegiatan anak termasuk pendidikan, bermain, serta trauma healing pada anak. Hal tersebut dilakukan tidak lain adalah sebagai upaya pemeliharaan jiwa (hifz al-nafs) dan bentuk sosial kemanusiaan.

\section{Daftar Pustaka}

Abu Zahrah, Muhammad, 2010, Ushul Fiqh, Jakarta: PT. Pustaka Firdaus.

Al- Syātibi. Abū Isḥāaq Ibrāhīm, 2000, al-Muwāfaqāt. vol. 2.

Al-Khadimi, Nuruddun AL-Mukhtar, 2006. Al-Munasabah Al-Syar'iyyah Wa Tatbiquha al-Mu'asiroh, Beirut: Dar Ibn Hazm,

Al-Zuhaili, Wahbah, Al-Fiqh al-Islami wa Adillatuh, 1989, (Damsyiq: Dar alFikr,), VII : 717. lihat juga Kamal Muchtar, Asas-asas Hukum Islam Tentang Perkawinan.

Anjasari, Santi dan Sri Hartini, 2018, Upaya Pengelola Program Penguatan Keluarga SOS Children's Village Indonesia dalam Mengurangi Jumlah Anak-anak yang Rentan Terlantar, Jurnal Comm-Edu Vol 1 No. 1

Asy-Syawi, Muhammad bin Shalih. Al-Nafahât al Makiyyah fi Tafsîr Kitab Rabb al-Bariyyah, Abekan, t.t.

Audah, Jasser. (2007), Maqāșid Al-Sharī’ah As Philosophy of Islamic Law: a System Approach (Washington: The International Institite of Islamic Thouht)

Gultom. Maidin, 2006, Perlindungan Hukum Terhadap Anak; Dalam Sistem Peradilan Pidana Anak di Indonesia, Bandung: Refika Aditama,.

Indriati, Noer, Krisnhoe K. Wahyuningsih, dan Sanyoto, 2017, Perlindungan dan Pemenuhan Hak Anak (Studi Tentang Orang Tua sebagai Buruh 
Migran di Kabupaten Banyumas), Jurnal Mimbar Hukum Vol 29 No. 3.

Katsir, Ismail Ibnu Umar Ibnu. (1419), Tafsîr al-Qur'ân al- 'Azhîm, (Beirut: Dar al-Kutub al-Islamiyah), jilid v.

Kemensos,http://www.pksa/kemensos.com/wpcontent/uploads/2011/01/Pedo man_PKSA_2011. diakses pada 1 Januari 2010 pada pukul 11.48 Wib

Kementrian Agama RI, 2014, Al-Qur'an Terjemah dan Tajwid, Bandung: Sygma,

Khalaf, Abd al-Wahhāb, Ilm Ușūl al-Fiqh. Surabaya: alHaramain, t.t.

Khalaf, Abdul Wahhab. (1942) 'Ilm ushul al-Fiqh (Kairo: Maktabah Dakwah Islamiyah)

Koto. Alaiddin, 2004, Ilmu Fiqh dan Ushul Fiqh, (Jakarta: PT. Raja Grafindo Persada).

Mujib. Abdul, Yusuf Mudzakir, 2003, Nuansa-nuansa Psikologi Islam, (Jakarta: PT. Raja Grafindo Persada).

Munawwir, Ahmad Warson, 1996, Kamus Al-Munawwir bahasa ArabIndonesia, Yogyakarta: Pustaka Progresif.

Peratutan Menteri Sosial RI No. 30/HUK/2011 tentang standar Nasional Pengasuhan Anak Lembaga Kesejahteraan Sosial Anak, Jakarta: Kementrian Sosial.

Shidiq, Sapiudin. 2011, Ushul Fiqh, Jakarta: Kharisma Putra Utama,.

SOS Kinderdorf International, 2004.

Sumarnonugroho. T, 1987, Sistem Intervensi kesejahteraan Sosial, Yogyakarta : PT Hanindit 
170 | FOKUS : Jurnal Kajian Keislaman dan Kemasyarakatan Vol. 5, No. 2, 2020

Halaman ini dikosongkan 